\title{
CARDIOBACTERIUM HOMINIS ENDOCARDITIS
}

\author{
Jenifer Midgley*, S. P. Lapage*, B. A. G. Jenkins $\dagger$, G. I. Barrow \\ M. E. Roberts@ AND A. G. BuCK\| \\ *National Collection of Type Cultures, Central Public Health Laboratory, Colindale Avenue, \\ London; †Department of Medicine and $\ddagger$ Public Health Laboratory, Royal Cornwall \\ Hospital (City), Truro, Cornwall; §Cardiology Department and \|Department of \\ Bacteriology, St Bartholomew's Hospital, London
}

IN 1964 Slotnick and Dougherty described a group of organisms previously referred to as "group IID", all of which were causative agents of bacterial endocarditis in man (Tucker et al., 1962; Slotnick and Dougherty; Slotnick, Mertz and Dougherty, 1964), and named them Cardiobacterium hominis. The present report deals with the isolation and identification of $C$. hominis from two cases of bacterial endocarditis. The species has not hitherto been reported in this country.

\section{CASE REPORTS \\ Case 1 \\ Clinical features}

On 6 June 1967 a housewife aged $35 \mathrm{yr}$ was admitted to the Royal Cornwall Hospital, Truro, with bacterial endocarditis. She had enjoyed normal health, although a heart murmur, considered innocent, had been noted 11 yr previously.

On 9 May 1967, after an uneventful first pregnancy, a healthy boy was delivered with forceps after external episiotomy. A retained placenta required manual removal, after which the perineum was sutured. Penicillin 1 mega unit was given the next day and 0.8 mega units with $2 \mathrm{~g}$ of streptomycin on each of the four following days. Two weeks later she gradually developed lassitude, exertional dyspnoea, a dry cough, profuse nocturnal sweats and a skin rash.

On admission, the positive clinical features included finger clubbing, erythema marginatum on the limbs and shoulders and severe periodontal infection. The pulse was regular, 110 per min., and the blood pressure 100/60. The apex beat was in the 5 th space in the left mid-clavicular line. There was left ventricular hypertrophy with an apical pansystolic murmur and thrill. Crepitations were heard at both lung bases and the spleen was enlarged $3 \mathrm{~cm}$.

The erythrocyte sedimentation rate (Wintrobe) was $45 \mathrm{~mm}$ in $1 \mathrm{hr}$, the leucocyte count 5000 per $\mathrm{mm}^{3}$ and the differential leucocyte count and the urine were normal. Blood was taken for culture on admission and on the next day, and she was then given 8 mega units of penicillin and $1 \mathrm{~g}$ of ampicillin daily. Four days later, as no organism had been isolated, the ampicillin was increased to $2 \mathrm{~g}$ daily and probenecid was given. On 17 June a small embolus occurred in the right little finger and, after a second embolus in the right forearm 5 days later, the daily antibiotics were increased to 12 mega units of penicillin, $6 \mathrm{~g}$ of ampicillin and $2 \mathrm{~g}$ of streptomycin. The periodontal infection was dealt with on 7 July by total extraction of the teeth under the additional cover of vancomycin $2 \mathrm{~g}$ by intravenous infusion.

Received 14 May 1969; accepted 30 June 1969.

J. MED. MICROBIOL.-VOL. 3 (1970)

91 
Antibiotic treatment was maintained for 36 days. The patient has remained well, and followup examinations to Nov. 1968 have revealed no evidence of active infection.

The cardiac lesion was considered to be a small ventricular septal defect with a small left to right shunt and low pulmonary vascular resistance.

\section{Bacteriology}

The organism was isolated from two out of three separate samples of blood taken from the patient for culture after her admission to hospital. On each occasion, 5-10 ml of blood were inoculated into each of three bottles containing $50 \mathrm{ml}$ of culture medium; one bottle contained glucose broth with added liquoid and penicillinase, the second contained bilesalt broth, and the third contained broth selective for brucella organisms. The air in the bottles of glucose broth and brucella broth was displaced with $\mathrm{CO}_{2}$ blown from a cylinder through a sterile Pasteur pipette plugged with cotton wool. This procedure would yield an atmosphere containing a high percentage of $\mathrm{CO}_{2}$. The bottles were kept at $37^{\circ} \mathrm{C}$ and subcultured on several occasions on to a variety of solid media for incubation for at least 3 days in the presence of $\mathrm{CO}_{2}$ under aerobic as well as under anaerobic conditions.

Apart from a coagulase-negative staphylococcus of doubtful significance isolated from one bile-salt broth, none of the blood cultures yielded any growth until after incubation for 13 days. On 21 June a scanty growth of tiny translucent colonies was observed on some of the plates which had been inoculated 3 days previously from two of the three glucose broth cultures. Antibiotic sensitivity tests were done and the organism was provisionally reported as an unidentified slow-growing micro-aerophilic Gram-variable rod. In agar cup tests, growth of the organism was inhibited by the following minimum concentrations of the antibiotics used in treatment of the patient; penicillin, 0.25 unit per ml, ampicillin, $0.25 \mu \mathrm{g}$ per $\mathrm{ml}$, and streptomycin, $4 \mu \mathrm{g}$ per $\mathrm{ml}$.

On first subculture, the organism grew well, though slowly, in a closed jar containing 20 per cent. added $\mathrm{CO}_{2}$. It grew less well anaerobically and no growth occurred under aerobic conditions in the incubator. It grew on nutrient agar medium, but growth was enhanced on chocolate agar plates.

Several different preparations of the organism were used in agglutination and complementfixation tests on two samples of the patient's serum, one taken on her admission to hospital and the other taken $9 \mathrm{mth}$ later. A satisfactory antigen for these tests was obtained from the growth on chocolate agar plates after incubation for 3 days in $\mathrm{CO}_{2}$. The growth was harvested and washed in saline, diluted to match Brown's tube no. 9 in opacity, and the suspension used after freezing at $-20^{\circ} \mathrm{C}$ and thawing. Suspensions of living organisms in saline or suspensions heated to $100^{\circ} \mathrm{C}$ gave equally satisfactory results in agglutination tests. The tests were performed on WHO plastic trays. Agglutination results were read after 24 and $48 \mathrm{hr}$ at $20^{\circ} \mathrm{C}$; the long fixation method described by Bradstreet and Taylor (1962) was used for the complement-fixation tests.

The serum obtained on admission gave titres of 320 and 640 respectively in agglutination and complement-fixation tests. The serum obtained 9 mth later gave an agglutination titre of 160 and thus showed little change, whereas the complement-fixation titre, which was 20 , had fallen considerably. Neither serum from the patient produced agglutination with a variety of other organisms isolated in the laboratory and, conversely, numerous sera from other patients failed to agglutinate this strain of $C$. hominis in slide tests.

\section{Case 2}

\section{Clinical features}

A 58-yr-old male stamp dealer was admitted to hospital on 20 Feb. 1968 with a 3-mth history of malaise and shortness of breath following an influenza-like illness. Four years earlier he had been investigated for attacks of chest pain, but no abnormalities were found apart from a severe iron deficiency anaemia due to bleeding haemorrhoids.

On initial examination during his current illness he had a temperature of $99^{\circ} \mathrm{F}\left(37 \cdot 2^{\circ} \mathrm{C}\right)$, 
but this settled before treatment. The signs of aortic incompetence were present together with mild congestive heart failure. Finger clubbing was observed, but other signs suggestive of bacterial endocarditis such as a palpable spleen, splinter haemorrhages and Osler's nodes were not found.

On admission, the erythrocyte sedimentation rate (Westergren) was $25 \mathrm{~mm}$ in $1 \mathrm{hr}$, the haemoglobin $11.7 \mathrm{~g}$ per $100 \mathrm{ml}$, the packed cell volume 36 per cent., and the leucocytes 6500 per $\mathrm{mm}^{3}$, of which 68 per cent. were polymorphs. The blood urea was $38 \mathrm{mg}$ per $100 \mathrm{ml}$ and the urine contained scanty blood red cells.

The patient was treated empirically from $23 \mathrm{Feb}$. with daily intravenous injections of 50 mega units of penicillin and $2 \mathrm{~g}$ of probenecid orally. He responded satisfactorily to this treatment which was maintained for $6 \mathrm{wk}$. The severe degree of aortic incompetence, however, remained and subsequently required aortic valve replacement in Aug. 1968. Two of the three valve cusps removed at operation were fibrotic and one showed nodular calcification, but histologically there was no sign of residual bacterial endocarditis. Since the operation the patient has continued to improve and in Jan. 1969 he was symptom-free and returned to work.

\section{Bacteriology}

Blood was taken for culture on each of the patient's first four days in hospital. On each occasion $7 \mathrm{ml}$ of blood was added to $0.5 \mathrm{ml}$ of 3.8 per cent. sodium citrate and $1-\mathrm{ml}$ volumes of the mixture were then placed in seven tubes, two containing $5 \mathrm{ml}$ of glucose broth, two with $5 \mathrm{ml}$ of nutrient broth, one with $15 \mathrm{ml}$ of Brewer's thioglycollate medium, and two containing $15 \mathrm{ml}$ of molten Oxoid blood base nutrient agar at $45^{\circ} \mathrm{C}$, from which pour plates were made. All cultures were incubated aerobically at $37^{\circ} \mathrm{C}$, the pour plates in an atmosphere with increased $\mathrm{CO}_{2}$ produced in a candle jar in which the exact concentration of $\mathrm{CO}_{2}$ was unknown. Each pour plate, after incubation for 6 days, and one tube of glucose broth yielded an organism later identified as $C$. hominis; the remaining cultures were discarded 14 days after inoculation.

The organism was a pleomorphic, irregularly staining rod. Subculture on to blood and chocolate agar plates yielded colonies up to $0.25 \mathrm{~mm}$ in diameter after 48 hours' incubation in an atmosphere containing added $\mathrm{CO}_{2}$. Growth was slower anaerobically and on plates incubated in a closed container without increased $\mathrm{CO}_{2}$. No growth was obtained on plates under aerobic conditions in the incubator.

In tube-dilution tests in broth, a large inoculum of the organism was killed by 0.18 units per $\mathrm{ml}$ of penicillin after 18 hours' incubation.

Agglutination was obtained with a suspension of the living organisms to a titre of 320 by serum obtained from the patient during his 2 nd wk in hospital.

\section{IDENTIFICATION OF STRAINS}

In the National Collection of Type Cultures all the tests for identification of the organisms were done according to the methods given by Cowan and Steel (1965). Both peptone water and serum water media were used to detect acid production from carbohydrates. The method of Cook (1950) for nitrate reduction was used in addition to the reaction in nitrate broth. Oxoid disks were used to determine X-and V-factor requirements and Oxoid Multodisks for antibiotic sensitivity tests.

The strains from case $1(\mathrm{~A} 80 / 67)$ and case $2(\mathrm{~A} 13 / 68)$ were compared with two strains of Cardiobacterium hominis, 6573 (NCTC10426) and 6574 (NCTC 10427), received from Dr I. J. Slotnick. The salient features and essential differences between these cultures are given in table $\mathrm{I}$. 


\section{Morphology}

All four cultures consisted of non-motile, non-sporing Gram-negative rods, $0.5-0.75 \mu \mathrm{m}$ wide and $1.5-3 \mu \mathrm{m}$ long. There was only slight pleomorphism though a few of the rods had swollen ends and there were some filaments. With Gram's method, some unevenness was noticed in the depth of staining

\section{TABLE I}

Biochemical reactions of the organisms isolated from case 1 and case 2 compared with two strains of Cardiobacterium hominis

\begin{tabular}{|c|c|c|c|c|}
\hline \multirow{2}{*}{ Test } & \multicolumn{4}{|c|}{ Reaction given in test by strain } \\
\hline & $\begin{array}{l}\text { A80/67 } \\
\text { (case 1) }\end{array}$ & $\begin{array}{l}\text { A13/68 } \\
\text { (case 2) }\end{array}$ & $\underset{(6573)}{\text { NCTC10426 }}$ & $\begin{array}{c}\text { NCTC10427 } \\
(6574)\end{array}$ \\
\hline $\begin{array}{l}\text { Catalase } \\
\text { Oxidase } \\
\text { Nitrate reduction } \\
\text { Indole } \\
\mathrm{H}_{2} \mathrm{~S} \\
\text { Methyl red after } 5 \text { days at } 30^{\circ} \mathrm{C} \\
\text { Voges-Proskauer after } 5 \text { days at } 30^{\circ} \mathrm{C} \\
\text { ONPG } \\
\text { Acid produced from:-- } \\
\text { adonitol } \\
\text { arabinose } \\
\text { dulcitol } \\
\text { galactose } \\
\text { glucose } \\
\text { glycerol } \\
\text { inositol } \\
\text { lactose } \\
\text { maltose } \\
\text { mannitol } \\
\text { rhamnose } \\
\text { salicin } \\
\text { sorbitol } \\
\text { sucrose } \\
\text { trehalose } \\
\text { xylose }\end{array}$ & $\begin{array}{l}- \\
\pm \\
+ \\
- \\
- \\
- \\
- \\
- \\
- \\
+ \\
- \\
+ \\
+ \\
- \\
- \\
+ \\
\pm \\
\pm\end{array}$ & 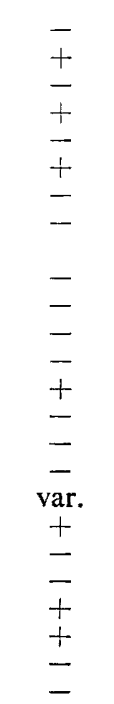 & $\begin{array}{l}- \\
\pm \\
+ \\
+ \\
+ \\
- \\
- \\
- \\
= \\
= \\
+ \\
= \\
= \\
- \\
\text { var. } \\
- \\
- \\
+ \\
+ \\
-\end{array}$ & $\begin{array}{l}- \\
+ \\
+ \\
+ \\
+ \\
- \\
- \\
- \\
= \\
= \\
\pm \\
- \\
- \\
+ \\
+ \\
\pm \\
+ \\
+ \\
+ \\
-\end{array}$ \\
\hline
\end{tabular}

var. $=$ Strain yields either a positive or negative result in repeated tests.

between individual cells and within the cells themselves. Neither metachromatic nor sudanophilic granules could be demonstrated in any of the strains with Albert's stain and sudan black respectively.

These findings are in contrast to those of Slotnick and Dougherty who described extreme pleomorphism ranging from Gram-negative rod-shaped cells to Gram-positive coccal cells; they were also able to demonstrate metachromatic and sudanophilic granules.

After $48 \mathrm{hr}$ on horse blood agar at $37^{\circ} \mathrm{C}$, the colonies were about $0.5 \mathrm{~mm}$ in diameter, circular and low convex in shape with a smooth surface. Their size increased to $1 \mathrm{~mm}$ in 3-4 days. There was no growth at $4^{\circ}$ or $22^{\circ} \mathrm{C}$, but 
growth was equally good at $30^{\circ}$ and $37^{\circ} \mathrm{C}$. Growth occurred on nutrient agar; it was not improved by the addition of $\mathrm{X}$ factor or $\mathrm{V}$ factor, or by that of both factors together.

All the strains grew well when incubated in a candle jar to increase the $\mathrm{CO}_{2}$. Strains A80/67, NCTC10426 and NCTC10427 grew equally well in a sealed jar without added $\mathrm{CO}_{2}$, but strain A13/68 grew less vigorously under these conditions. None of the strains grew well when the plates were placed on a shelf in the incubator, but all of them grew well under strictly anaerobic conditions.

\section{Biochemical tests}

All four cultures gave a positive oxidase reaction, produced indole and yielded a fermentative reaction in Hugh and Leifson's test. Acid but no gas was produced from glucose, sorbitol and sucrose. With maltose and mannitol the results differed among the strains (table I). Acid was not produced in adonitol, arabinose, dulcitol, galactose, glycerol, inositol, lactose, rhamnose, salicin, trehalose or xylose, nor was the presence of $\beta$-galactosidase demonstrated.

Slotnick and Dougherty were able to demonstrate $\mathrm{H}_{2} \mathrm{~S}$ production with lead acetate papers, but did not specify the growth medium; in our hands three strains, including NCTC10427 from Dr Slotnick, failed to produce $\mathrm{H}_{2} \mathrm{~S}$ when tested with a lead acetate paper suspended above nutrient broth reinforced with cysteine.

None of the organisms produced catalase or reduced nitrates. They did not grow in Koser's citrate, Møller's potassium cyanide or MacConkey's media, and did not hydrolyse gelatin or urea, oxidise gluconate, utilise malonate or deaminate phenylalanine, nor did they produce a decarboxylase for lysine and ornithine, or a dihydrolase for arginine.

\section{Antibiotic sensitivity}

All four cultures were sensitive to disks containing 1.5 units of penicillin, $10 \mu \mathrm{g}$ streptomycin, $10 \mu \mathrm{g}$ tetracycline, $10 \mu \mathrm{g}$ chloramphenicol, $10 \mu \mathrm{g}$ erythromycin, or $2 \mu \mathrm{g}$ ampicillin.

\section{Discussion}

In all the recorded cases of infection with Cardiobacterium hominis, including both of the patients reported in this paper, congenital or pre-existing cardiac lesions were present. In case 1 there was a small ventricular septal defect and in case 2 there was aortic incompetence, although no cardiac abnormality had been detected $4 \mathrm{yr}$ previously. The cardiac lesions presumably provided nonreactive environmental conditions suitable for this slow-growing opportunist organism. The source of the organism is obscure in both cases, although in case 1 infection of the uterus possibly occurred after delivery or manual removal of the placenta, despite subsequent prophylactic penicillin and streptomycin. Dental infection, often associated with bacterial endocarditis, was also 
present. There were no unusual clinical features of subacute bacterial endocarditis in either of the patients, although pyrexia was not a feature in case 1 and in neither case was a leucocytosis observed. The course of infection was typical of bacterial endocarditis and the response to antibiotic treatment was satisfactory in both patients. The absence of a leucocyte response was also noted by Speller, Prout and Saunders (1968), who isolated an organism closely resembling $C$. hominis from a patient with bacterial endocarditis.

The isolation of pleomorphic Gram-negative bacteria in blood culture from patients with endocarditis has been described frequently. The identification of these organisms is often difficult. Those likely to be confused with

TABLE II

Comparison of some features of Cardiobacterium hominis and three other similar organisms

\begin{tabular}{|c|c|c|c|c|}
\hline \multirow[b]{2}{*}{ Test } & \multicolumn{4}{|c|}{ Reaction given in test by } \\
\hline & $\begin{array}{l}\text { Cardiobacterium } \\
\text { hominis }\end{array}$ & $\begin{array}{l}\text { Actinobacillus } \\
\text { actinomycetem- } \\
\text { comitans }\end{array}$ & $\begin{array}{l}\text { Haemophilus } \\
\text { aphrophilus }\end{array}$ & $\begin{array}{l}\text { Streptobacillus } \\
\text { moniliformis }\end{array}$ \\
\hline $\begin{array}{l}\text { Catalase } \\
\text { Oxidase } \\
\text { Nitrate reduction } \\
\text { Indole } \\
\text { Methyl red } \\
\text { Acid produced from:- } \\
\quad \text { lactose } \\
\text { mannitol } \\
\text { salicin } \\
\text { sorbitol } \\
\text { sucrose } \\
\text { xylose }\end{array}$ & $\begin{array}{l}-\overline{+} \\
\pm \\
\overline{+} \\
\mathrm{d} \\
\overline{\mathrm{d}} \\
\frac{-}{+} \\
+ \\
+\end{array}$ & $\begin{array}{l} \pm \\
\pm \\
\pm \\
- \\
- \\
\pm \\
- \\
\bar{d}\end{array}$ & $\begin{array}{l}- \\
\overline{+} \\
\pm \\
- \\
\pm \\
= \\
- \\
+\end{array}$ & $\begin{array}{l}- \\
\overline{-} \\
\overline{-} \\
\mathrm{d} \\
+ \\
\overline{+} \\
-\end{array}$ \\
\hline
\end{tabular}

$\mathrm{d}=$ Reaction differs among different strains of the species.

C. hominis are Haemophilus aphrophilus, Actinobacillus actinomycetemcomitans and Streptobacillus moniliformis. All these species may require or appear to require increased $\mathrm{CO}_{2}$ in the atmosphere for growth, particularly on first isolation. Strains of $H$. aphrophilus and A. actinomycetemcomitans may, however, lose this requirement on subculture. The main differences between these species are summarised in table II.

Several species of Haemophilus are known to cause endocarditis in man, e.g., H. influenzae (Rose, 1941), H. parainfluenzae (Craven, Poston and Orgain, 1940), and $H$. aphrophilus (Khairat, 1940; Keith and Lyon, 1963; Witorsch and Gorden, 1964; Page and King, 1966). Difficulty in identification was reported by Stuart-Harris et al. (1935) with four $H$. parainfluenzae-like strains and by Russell (1965) with a strain of $H$. aphrophilus. More recently Speller et al. described an organism similar to $H$. aphrophilus, although its characters resemble more closely those of $C$. hominis. H. aphrophilus differs from 
C. hominis in producing acid from lactose, and in its failure to produce indole and oxidase. Strains of $H$. aphrophilus may require $\mathrm{X}$ factor for growth.

$A$. actinomycetemcomitans and $H$. aphrophilus are closely related to each other and should probably be combined in one genus. The differences between these two species are described fully by King and Tatum (1962), who also distinguished four biotypes in the case of A. actinomycetemcomitans. Recently isolated strains studied at the National Collection of Type Cultures are clearly members of this group, but do not fit the typical description of either species nor the other biotypes. The occurrence of $A$. actinomycetemcomitans in bacterial endocarditis has been described by Mitchell and Gillespie (1964), Overholt (1966) and Vogelzang (1967). Typical strains of A. actinomycetemcomitans may be distinguished from $C$. hominis by the production of catalase, by negative indole and oxidase reactions and by the failure to produce acid from sucrose.

S. moniliformis was first described in bacterial endocarditis by Blake (1916). In 1967, McCormack, Kaye and Hook cited nine cases from the literature and described two further ones. Cultures of $S$. moniliformis are more fastidious than those of $C$. hominis, and they usually require a high proportion of blood or serum in the medium, and need incubation for 3-5 days before growth appears. Both species may exhibit club forms, filaments, swollen rods and some of the cells in young cultures may retain the Gram stain. Cultures of $S$. moniliformis attack few carbohydrates and produce only weak acid slowly. They do, however, attack salicin which is not attacked by $C$. hominis and they give negative indole and oxidase reactions.

The identification of $C$. hominis should not present difficulty provided that the possibility of its occurrence is kept in mind. On first isolation there may be an apparent requirement for $\mathrm{X}$ factor or for $\mathrm{CO}_{2}$, and perhaps only a weak action on carbohydrates. Further subcultures may be necessary for the demonstration of the typical characteristics of the organism.

\section{SUMMARY}

The isolation of Cardiobacterium hominis from two patients with bacterial endocarditis is reported, and the clinical features are described.

These strains of $C$. hominis produced small, shiny, convex colonies visible within a week on first isolation. After further subcultures, colonies were visible within 2 days. Isolation was achieved on blood or chocolate media with added $\mathrm{CO}_{2}$. When examined later the strains did not require $\mathrm{CO}_{2}$, but growth was improved by moisture.

They gave a positive oxidase reaction and produced indole, but did not produce catalase or reduce nitrates; this pattern of reactions should serve to distinguish them from strains of Haemophilus aphrophilus, Actinobacillus actinomycetemcomitans and Streptobacillus moniliformis.

We wish to thank Dr I. J. Slotnick for confirming the identity of strain A80/67. We are grateful to Dr R. V. Gibson who examined the cardiac condition of case 1, Dr G. W. Hayward for permission to publish the clinical details of case 2, and to $\mathrm{Mr} \mathrm{J}$. Bagnall, Truro, and Mr J. J. S. Snell, Colindale, for technical assistance. 


\section{REFERENCES}

Blake, F. G. . . . . . . . 1916. J. Exp. Med., 23, 39.

Bradstreet, C. M. Patricia, and 1962. Mon. Bull. Minist. Hlth, 21, 96.

TAYLOR, C. E. D.

Cook, G. T. . . . . . . 1950. J. Clin. Path., 3, 359.

CowAN, S. T., AND STEEL, K. J. . . 1965. Manual for the identification of medical

Craven, E. B., JR, Poston, Mary A., 1940. Amer. Heart J., 19, 434.

AND ORgain, E. S.

Keith, T. A., AND Lyon, S. A. 1963. Amer. J. Med., 34, 535.

Khairat, O. . . . . . 1940. J. Path. Bact., 50, 497.

King, Elizabeth O., and Tatum, H. W. 1962. J. Infect. Dis., 111, 85.

McCormack, Regina C., Kaye, D., AND 1967. J. Amer. Med. Assoc., 200, 77. HoOK, E. W.

Mitchell, R. G., ANd Gillespie, W. A. 1964. J. Clin. Path., 17, 511.

OVerholt, B. F. . . . . . . 1966. Archs Intern. Med., 117, 99.

Page, M. I., ANd King, Elizabeth O. . 1966. New Engl. J. Med., 275, 181.

Rose, H. M. . . . . . . 1941. Amer. J. Med. Sci., 202, 187.

Russell, J. P. . . . 1965. Amer. J. Clin. Path., 44, 86.

SlotNick, I. J., AND Dougherty, Mary 1964. Antonie van Leeuwenhoek, 30, 261.

Slotnick, I. J., Mertz, Jo AnN, AND 1964. J. Infect. Dis., 114, 503. DOUgherTy, MARY

Speller, D. C. E., Prout, B. J., ANd 1968. J. Path. Bact., 95, 191. SAUnders, C. F.

Stuart-Harris, C. H., Wells, A. Q., 1935. Ibid., 41, 407.

Rosher, A. B., MACKIE, F. P., AND WILSON, G. S.

Tucker, D. N., Slotnick, I. J., King, 1962. New Engl. J. Med., 267, 913. Elizabeth O., Tynes, B., Nicholson, J., AND CRevasse, $\mathbf{L}$.

VOGELZANG, R. M.

1967. Archs Intern. Med., 120, 99.

Witorsch, P., AND GoRden, P. . . 1964. Ann. Intern. Med., 60, 957. 